\title{
Expression of a retinoblastoma transgene results in dwarf mice
}

\author{
Yves-Jean Bignon, ${ }^{1,3}$ Yumay Chen, ${ }^{1}$ Chi-Yao Chang, ${ }^{1}$ Daniel J. Riley, ${ }^{1}$ Jolene J. Windle, ${ }^{2,4}$ \\ Pamela L. Mellon, ${ }^{2}$ and Wen-Hwa Lee ${ }^{1,5}$ \\ ${ }^{1}$ Center for Molecular Medicine/Institute of Biotechnology, The University of Texas Health Science Center at San Antonio, \\ San Antonio , Texas 78245 USA; ${ }^{2}$ Salk Institute, La Jolla, California 92037 USA
}

\begin{abstract}
Introduction of the normal retinoblastoma gene $(\mathbf{R B})$ into different tumor cells possessing inactivated $R B$ genes suppresses their tumorigenicity in nude mice. These results suggest that $R B$ replacement is a potential strategy for developing future clinical treatments of cancer. In a transgenic mouse model, we found that the quantity of RB protein in a given cell may play an important role in dictating its effect. Four founder mice containing 1-7 copies of a human RB cDNA transgene under the transcriptional control of the human RB promoter were generated. Most of the transgenic mice were smaller than nontransgenic littermates. This effect was found as early as embryonic day 15. The degree of dwarfism correlated roughly with the copy number of the transgene and the corresponding level of RB protein. The expression pattern of the transgene products was similar to that of the endogenous mouse RB gene with regard to tissue and temporal distribution. Transferring the transgene to RB deficient mice, which are nonviable, resulted in the development of normal, healthy mice, indicating that the human RB gene can functionally complement the mouse homolog. These studies demonstrate that the effect of RB on overall mouse development is closely dependent upon its dosage.
\end{abstract}

[Key Words: Retinoblastoma gene; growth; dwarf; transgenic mice]

Received June 17, 1993; revised version accepted July 22, 1993.

The retinoblastoma gene $(R B)$, mutation of which is responsible for the hereditary predisposition to retinoblastoma (Friend et al. 1986; Fung et al. 1987; Lee et al. 1987a), encodes a nuclear phosphoprotein that is ubiquitously expressed in most normal cells of vertebrates (Lee et al. 1987b). In addition to retinoblastoma, mutations of $\mathrm{RB}$ have been found in many different adult human cancers (Lee et al. 1988). Reintroduction of the wild-type RB gene into these tumor cells suppresses their neoplastic properties (Huang et al. 1988; Bookstein et al. 1990; Sumegi et al. 1990; Takahashi et al. 1991; Goodrich et al. 1992), demonstrating that the RB gene is a general tumor suppressor.

The RB gene is evolutionarily conserved in vertebrates (Friend et al. 1987; Lee et al. 1987a). The difference between mouse and human RB is very subtle (Bernards et al. 1989); the human RB protein has 928 amino acids, but the mouse RB protein has only 926 amino acids. The overall homology is high and the identity $\sim 91 \%$ (Bernards et al. 1989). Nevertheless, the differences enable us to distinguish these two proteins either biochemically by SDS-PAGE or immunologically by specific antibodies

Present addresses: ${ }^{3}$ Laboratoire $D^{\prime}$ Oncologie Moleculaire, Centre Jean Perrin, Clermont-Ferrand, France; ${ }^{4}$ Cancer Therapy and Research Center, UT Health Science Center, San Antonio, Texas 78229 USA.

${ }^{5}$ Corresponding author.
(Shew et al. 1989). Many studies have suggested that RB is regulated by phosphorylation (Buchkovich et al. 1989; Chen et al. 1989; DeCaprio et al. 1989). The responsible kinases are probably members of the cdc2 kinase family, as most of the phosphorylated residues of RB found in vivo are identical to those phosphorylated in vitro by purified cdc2 kinase (Lees et al. 1991; Lin et al. 1991). It has been proposed that the phosphorylated form of the $\mathrm{RB}$ protein is inactive while the unphosphorylated form, mainly found in $G_{0}$ and $G_{1}$ phases, is functional in blocking progression of the cell cycle. Direct microinjection of purifed, hypophosphorylated RB into cells at early $G_{1}$ inhibits cell cycle progression, suggesting that $R B$ may function in gating entry into $S$ phase /Goodrich et al. 1991). Inactivation of the RB protein by phosphorylation, mutation (Horowitz et al. 1989; Bignon et al. 1990; Shew et al. 1990) or binding by viral oncoproteins (DeCaprio et al. 1988; Whyte et al. 1988) results in deregulation of the gated control into the cell cycle. This simplified model may explain how deregulation of RB protein leads to cancerous growth of cells.

To further explore the role of $\mathrm{RB}$, mice with the genotype $\mathrm{Rb} / \mathrm{Rb}^{\mathrm{m}}(\mathrm{m}=$ mutated at exon 20$)$ were generated through stem cell knockout techniques (Lee et al. 1992). Phenotypically, the heterozygotes appear normal in all regards except that pituitary tumors occur late in life. Interestingly, homozygotes with both alleles of the RB 
gene mutated are nonviable, having defects in neuronal and hematopoietic systems. Ectopic mitosis, cell death, and failure to differentiate into mature blood cells were observed in these tissues, indicating that deficiency in $\mathrm{RB}$ results in deregulated cell growth and differentiation. These results suggested that the RB gene is essential for mouse development.

The amount of RB protein appears to vary in different cell types. Fibroblasts contain the lowest level of RB protein, whereas blood and neuronal cells contain amounts that are more easily detectable (P.-L. Chen, unpubl.). This difference may be important to each individual cell type in terms of overall differentiation, although the exact mechanism is not known. Mammalian cells stably expressing high levels of RB protein have been difficult to obtain, suggesting that the level of RB protein may be critical to cell growth (Huang et al. 1988). Cytostatic effects of RB have been reported, on the basis of a transfection method that introduced hundreds of copies of the gene transiently (Templeton et al. 1991; Qin et al. 1992). To address this dosage problem more precisely, we have employed transgenic mice carrying additional copies of the RB gene as a model system. Our data suggest that overexpression of $\mathrm{RB}$ protein inversely correlates with the size of mice, reflecting the sensitivity to dosage of the RB protein.

\section{Results \\ Construction of the human $R B$ transgene and generation of $R B$ transgenic mice}

The transgene was constructed by linking the $2.8 \mathrm{-kb}$ human RB cDNA containing the entire coding sequence (Wang et al. 1990b) to the human 1.6-kb RB promoter, which was defined by a transfection assay in culture cells (Hong et al. 1989), and the 1.6-kb human $\beta$-globin poly(A) region (Fig. 1A). Human RB was chosen because of its high homology to mouse RB (Bernards et al. 1989); still, the two genes and their proteins can be distinguished biochemically and immunologically (Shew et al. 1989). Such a construct is expected to be expressed in most tissues, as the RB promoter is similar to housekeeping promoters that are expressed ubiquitously (Lee et al. 1987a; Hong et al. 1989).

Four founder mice, RB.Rb-1 (male), RB.Rb-2 (female), RB.Rb-3 (female), and RB.Rb-4 (male), were identified by tail DNA analysis, and lines of mice were established from each. To determine the copy number of the transgene in each founder line, genomic DNA was analyzed by digesting with $B a m H I$ and probing Southern blots with a DNA fragment containing the entire transgene. On the basis of the presence of the 2.8 -kb band at singlecopy density and the absence of the $3.2-\mathrm{kb}$ fusion fragment [consisting of either two $1.6-\mathrm{kb} \mathrm{RB}$ promoter or poly(A) site fragments], RB.Rb-2 contains one copy of the transgene at a unique integration site (Fig. 1B). The intensities of the $2.8-\mathrm{kb}$ band indicate that the copy number of the other founders is two for RB.Rb-4, three for RB.Rb-3, and seven for RB.Rb-1. The internal hybridiza-
A

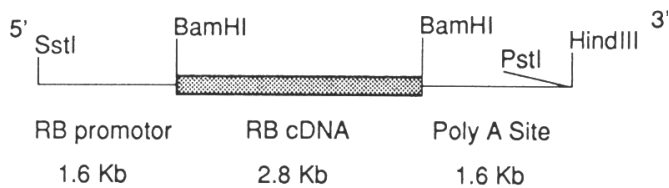

B
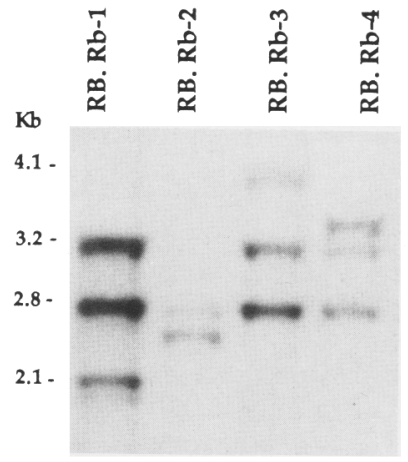

Densitometry : $\quad \begin{array}{llll}7.2 & 1 & 3.1 & 2\end{array}$

Figure 1. (A) Map of the 6-kb RB transgene. Three DNA fragments including the $1.6-\mathrm{kb}$ RB promoter, the $2.8-\mathrm{kb}$ RB cDNA, and a $1.6-\mathrm{kb} \beta$-globin clone containing a polyadenylation site were used to construct the $\mathrm{pBR}-\mathrm{RB} . \mathrm{Rb}$ plasmid. The 6-kb SstIHindIII DNA fragment containing the transgene was isolated for microinjection. $(B)$ Identification of transgenic founder lines by Southern blot analysis. Ten micrograms of tail DNA from each founder mouse was digested with restriction enzyme BamHI; the blot was hybridized with the HindIII-SstI 6-kb DNA fragment in $50 \%$ formamide and washed using stringent conditions to avoid cross hybridization with the endogenous $R B$ gene. Densitometry of the autoradiograms was performed with a LKB Ultroscan XL densitometer. Densitometry indicates the number of copies of the human $\mathrm{Rb}$ gene.

tion standard used to calibrate the genomic DNA was a 5.7-kb DNA fragment encoding the mouse single-copy p53 gene (Bienz 1984, and as shown in Fig. 5, below). To characterize further the structural organization of the transgene in later generations, genomic DNA from the offspring of each founder was analyzed by DNA blotting, probing with different fragments of the transgene DNA. As shown in Figure 2, RB.Rb-2 has a unique copy of the transgene with two identifiable integration fragments. RB.Rb-3 has three copies in a tandem repeat, with a unique integration site. RB.Rb-4 has two copies of the transgene tandemly arrayed in a single integration site. Similar analysis in many generations of transgenic mice indicated that transgenes in these three lines of mice appeared to be very stable. However, the copy number of the transgene of RB.Rb-1 varied. As shown in Figures 1 and 3 , the original founder has seven copies of the transgene, whereas the progeny of later generations derived from this founder contain one, three, four, or five copies with identical integration sites. Apparently, an internal deletion without involving the junctional fragments had taken place through homologous recombination. For further studies, the later progeny of RB.Rb-1 were genotyped individually to determine their copy number. Each 
Figure 2. Genomic organization of the transgene in mice by Southern blot analysis. Tail DNA from mice in each transgenic line was analyzed by DNA blotting, using probes representing different portions of the transgene, as indicated. The copy number was determined by Betascope. Unique junctional fragments of each transgene indicate that there is a single integration site for each transgene.

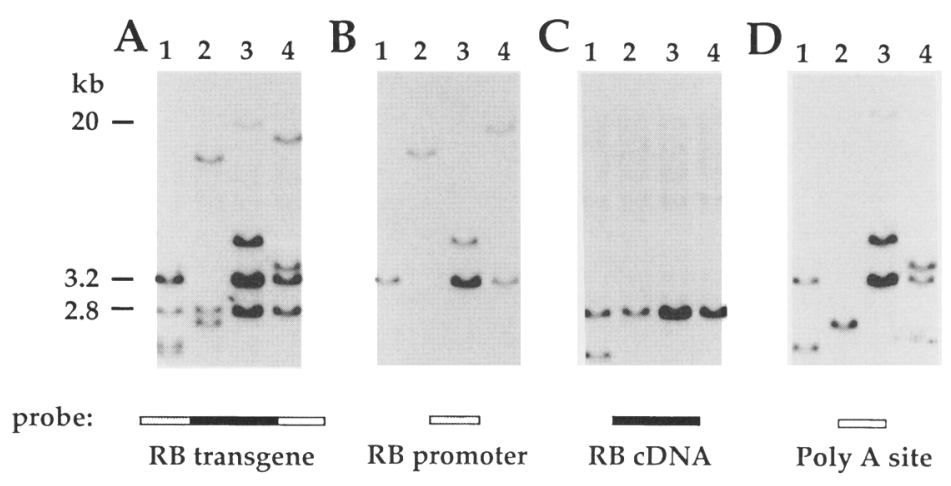

RB Rb-1

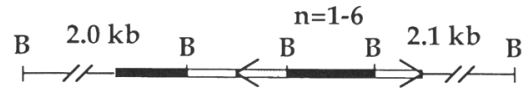

RB Rb-2

B $10 \mathrm{~kb} \quad$ B $\quad$ B $2.5 \mathrm{~kb} \quad$ B

RB Rb-3

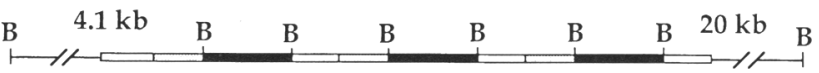

$\mathrm{RB} \mathrm{Rb}-4$ founder may have a unique autosomal integration site, because many generations of transgenic progeny of both sexes share identical patterns of the junctional fragments.

\section{Phenotype of $R B$ transgenic mice: dwarfism}

Backcrosses of male founders with BALB/c or C57BL/ 6 females showed that most, if not all, transgenic mice had the same phenotype: They were consistently smaller than their nontransgenic littermates of the same sex. This tendency toward being undersized was observed in each of the founder lines, suggesting that the phenotype was not a result of the integration site. No apparent histological abnormalities were detected in any organs,

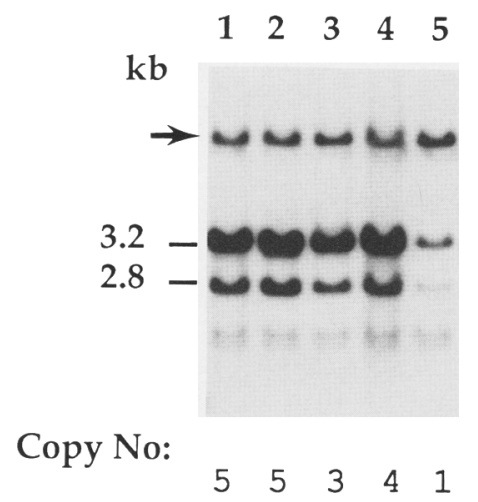

Figure 3. Reduction of the copy number of the transgene in the RB.Rb-1 strain. DNA fragments from the transgenic offspring of the original founder RB.Rb-1 were analyzed by Southern blots probed with the entire transgene. Lanes 1 and 2 were from $F_{1}$ mice; lanes 3 and 4 were from the intercross of $F_{1}$ mice, and lane 5 was from later crosses. which had sizes and weights proportional to the total body weight. Except for a few cases in the RB.Rb-2 and RB.Rb-4 strains, the distinctive phenotype allows one to easily distinguish transgenic mice from nontransgenic mice within the same litter.

To better characterize the effects of the transgene, male founders were backcrossed several times to obtain at least 14 mice in each line; these mice were then weighed every 2 days until 70 days postweaning. By comparing individuals of the same sex within a litter, a statistically significant difference in weight between transgenic and nontransgenic mice was observed in all the lines. The greatest difference in body weight was observed in the RB.Rb-3 line; these mice had mean body masses $28 \%$ less than their nontransgenic sibs (Table 1 ). Mice from the RB.Rb-1 (containing three to five copies of the transgene) and RB.Rb-4 lines were both a mean $19 \%$ lighter than nontransgenic sibs. Females of the RB.Rb-2 strain were only slightly smaller than their nontransgenic sibs, but together all RB.Rb-2 mice were $\sim 12 \%$

Table 1. Dwarfism in human $R b$ transgenic mice compared with wild-type littermates

\begin{tabular}{|c|c|c|c|c|}
\hline Founder & Number & $\begin{array}{l}\text { Mass in } \\
\text { grams } \\
\text { (mean } \\
\pm 95 \% \text { C.I.) }\end{array}$ & $\begin{array}{l}\text { Mean } \\
\text { difference } \\
\text { in body } \\
\text { mass }(\%)\end{array}$ & $\begin{array}{l}\text { Significance } \\
\text { by Student's } \\
\text { t-test }(P)\end{array}$ \\
\hline $\begin{array}{l}\text { RB.Rbl } \\
\text { wild-type }\end{array}$ & $\begin{array}{l}14 \\
15\end{array}$ & $\begin{array}{l}11.4 \pm 1.8 \\
14.1 \pm 1.9\end{array}$ & -19.1 & 0.0077 \\
\hline $\begin{array}{l}\text { RB.Rb2 } \\
\text { wild-type }\end{array}$ & $\begin{array}{l}5 \\
9\end{array}$ & $\begin{array}{l}15.4 \pm 1.9 \\
17.4 \pm 1.5\end{array}$ & -11.7 & 0.030 \\
\hline $\begin{array}{l}\text { RB.Rb3 } \\
\text { wild-type }\end{array}$ & $\begin{array}{l}12 \\
14\end{array}$ & $\begin{array}{l}10.9 \pm 0.54 \\
15.2 \pm 0.72\end{array}$ & -28.0 & 0.0001 \\
\hline $\begin{array}{l}\text { RB.Rb4 } \\
\text { wild-type }\end{array}$ & $\begin{array}{l}9 \\
9\end{array}$ & $\begin{array}{l}13.1 \pm 1.4 \\
16.2 \pm 1.5\end{array}$ & -19.0 & 0.0067 \\
\hline
\end{tabular}


smaller. An example of growth curves of one litter from each individual line is shown in Figure 4. The growth rate of each transgenic line appeared to be very similar, and the size differences between transgenic and non- transgenic sibs is obvious. The degree of the difference roughly correlates with the copy number of the transgene. Differences in body mass between RB.Rb-1 mice and their wild-type littermates, although the mean dif-
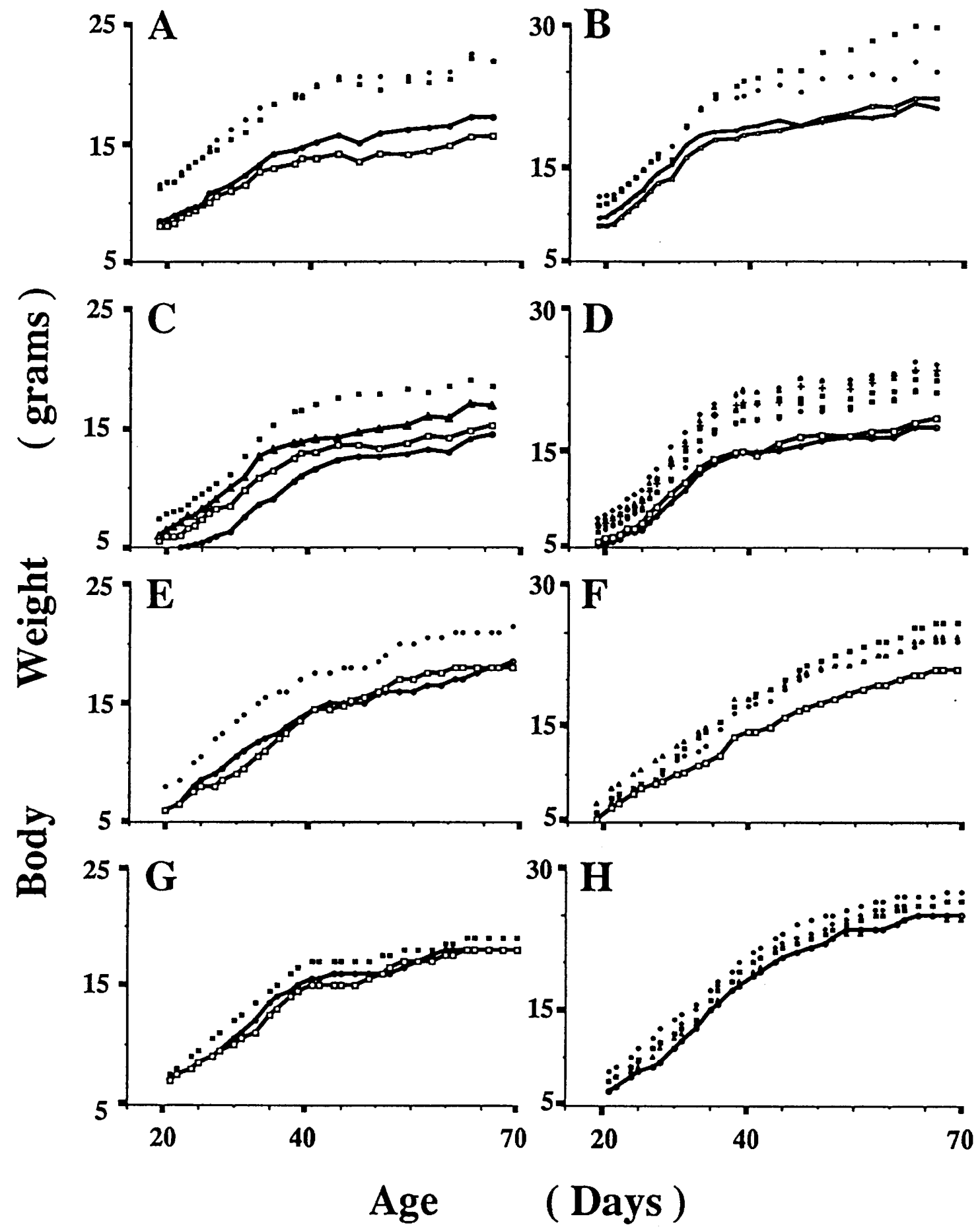

Figure 4. Individual growth curves of all transgenic and nontransgenic sibs derived from the same litter. Solid lines correspond to the growth curves of the transgenic mice; dashed lines represent the nontransgenic mice. After weaning, the mice were labeled and separated according to sex. Their total body mass was determined every other day. Females $(A)$ and males $(B)$ from the RB.Rb 1 strain, which contain three to five copies of the transgene; females $(C)$ and males $(D)$ from the RB.Rb 3 strain; females $(E)$ and males $(F)$ from the RB.Rb 4 strain; females $(G)$ and males $(H)$ from the RB.Rb 2 strain. 
ferences were highly significant, were smaller than expected for the transgene copy number, in part because the copy number was not constant in all the RB.Rb-1 mice. Continuous observation of all transgenic mice for $>20$ months has demonstrated that they never develop any particular disease or other unusual phenotype. They breed normally and their temporal program of development is normal, except for the smallest mice, which open their eyes a few days later than their normal siblings.

\section{Embryo sizes also correlate inversely with the transgene copy number}

To further address the effects of $\mathrm{RB}$, fetuses from pregnant transgenic mice were weighed and their genotypes were analyzed by DNA blotting. As shown in Figure 5A, among the ten 15-day old fetuses obtained from a cross of two heterozygous RB.Rb-3 mice, the two smallest fetuses $(388$ and $480 \mathrm{mg}$ ) have a homozygous genotype (genotype $3+3$ ). Five heterozygous fetuses (genotype 3 ) were of medium weight, and three nontransgenic (genotype 0 ) were the heaviest. When 17-day-old fetuses from the cross of RB.Rb-1, which has two copies of the transgene, and RB.Rb-3 mice were analyzed, the order of decreasing size was nontransgenic, RB.Rb-1, RB.Rb-3, and RB.Rb- $(1+3)$, respectively (Fig. $5 B)$. These results dem-

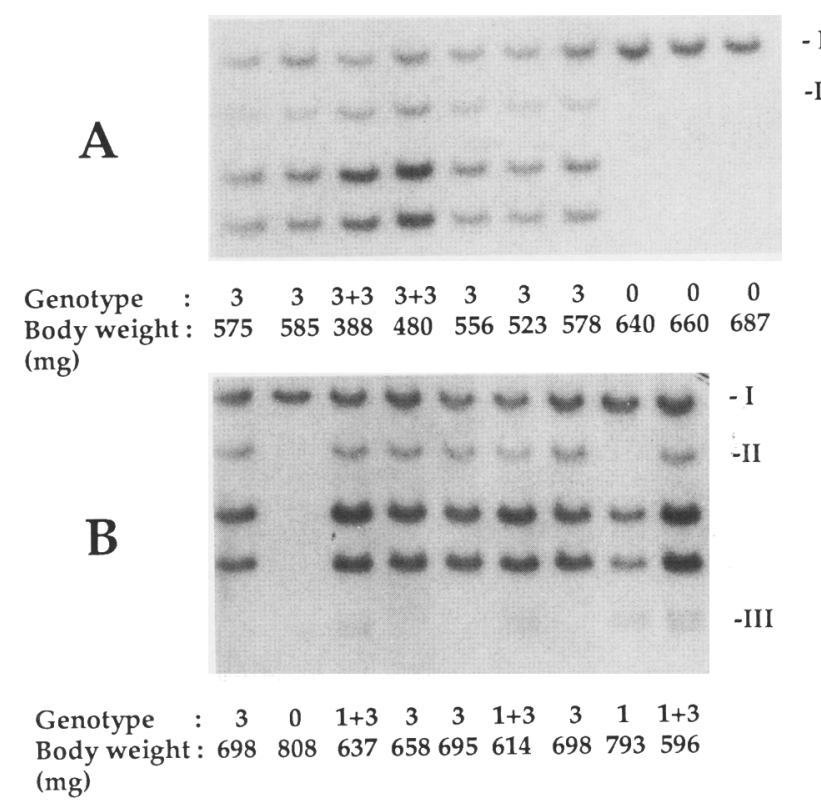

Figure 5. Dwarfism was detected in the fetal stage of transgenic mouse development. Fetuses (15-17 days old) from RB.Rb-3 $\times$ RB.Rb-3 $(A)$ and RB.Rb-1 $\times$ RB.Rb-3 (B) were collected as described (Hogan et al. 1986), and their total body weights were measured. Genotypes of these fetuses were determined by extracting genomic DNA from a portion of the yolk sac for Southern blot analysis, as described in Figure 1. The bands compared were the $5.7-\mathrm{kb}$ fragment of p53, labeled $I$, a unique integration fragment of RB.Rb-3, labeled $I I$, and the integration fragment of RB.Rb-1, labeled III.

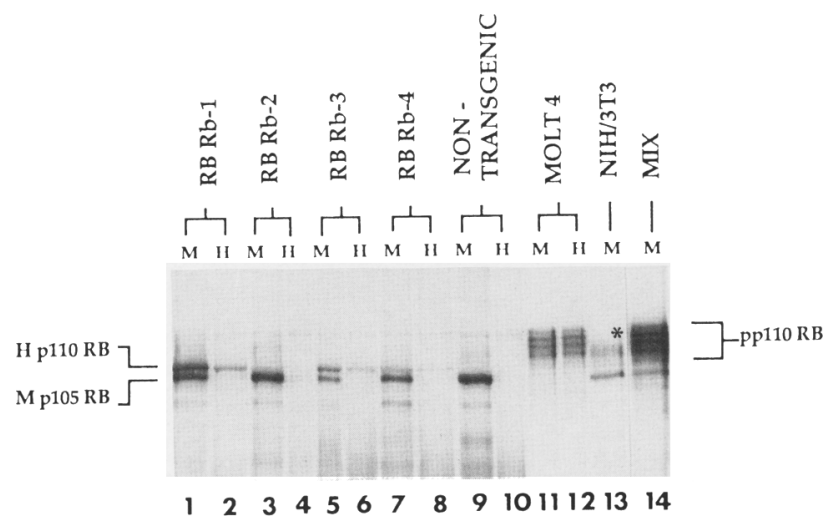

Figure 6. Expression of the transgenic RB protein in the lungs of the four mouse lines by Western blot analysis. Human T-cell leukemia (Molt-4) cells were used as positive control for human $\mathrm{RB}$ protein, and NIH-3T3 cells were used as positive control for mouse RB protein. Ten milligrams of protein lysates from these cells or from dissected lung tissues was used for immunoprecipitation by antibodies, mAb 245 (labeled $M$ for mouse) and 0.495 (labeled $\mathrm{H}$ for human), to distinguish the endogenous and human RB proteins. The immunoprecipitates were analyzed by Western blotting analysis and probed with mAb 245.

onstrate that the copy number of the transgene correlates inversely with the embryo sizes, suggesting that more $\mathrm{RB}$ somehow interferes with the overall growth of the mice beginning during early embryogenesis.

\section{Expression levels of the transgene}

To examine the expression of the transgene product in each line, equal amounts of lung tissue from each line were used for a determination of the exogenous human RB protein by Western blotting (Fig. 6). The 0.495 polyclonal antibody, which predominantly recognizes the human RB protein (Wang et al. 1990a), and the monoclonal antibody mAb 245 , which recognizes both the human and mouse RB proteins, were used to probe the blots. All four lines expressed detectable human RB protein (Fig. 6). Strictly, only comparison of the level of expression of human RB can be done with certainty. The relative affinities of the antibodies for human and mouse $\mathrm{RB}$ proteins may be different, and such affinities are difficult to determine precisely. If we make the assumption that the affinity of $\mathrm{mAb} 245$ for human and mouse $\mathrm{RB}$ proteins is nearly equivalent-a reasonable assumption in immunoprecipitation, as the antibody is present in great excess compared with the antigen and should therefore precipitate the vast majority of all $\mathrm{RB}$ protein present in the sample-we can also compare RB protein expression in transgenic mice and mice expressing only endogenous mouse RB protein. The expression level of the transgenic compared with the endogenous RB protein was $\sim 1: 1$ in lines of RB.Rb-1 and RB.Rb-3 (lanes 1,5 ), was $<0.5: 1$ in RB.Rb-4 (lane 7), and was very low in RB.Rb-2 (lane 3). The expression is roughly proportional to the transgene copy number, suggesting a direct rela- 
tionship between the copy number of the transgene, expression level of the transgenic protein, and the degree of dwarfism.

\section{The transgene is expressed ubiquitously}

The RB gene has been shown to be expressed in all cell types examined. It was important to address whether the expression of the human RB promoter-driven transgene is similar to that of the endogenous mouse RB. Cell lysates prepared from different organs of RB.Rb-3 mice, including brain, thymus, spleen, muscle, and testis, were used for Western blot analysis. As shown in Figure 7A, all of the tissues examined contained the transgenic human $\mathrm{RB}$ protein. Immunostaining of different tissues from RB.Rb-3 mice with the 0.475 polyclonal antibody was also positive in most of the tissues examined (data not shown). To examine further whether the transgene expresses its protein during embryogenesis, embryos at different stages of development were obtained for $\mathrm{RB}$ protein analysis. As shown in Figure 7B, both the transgenic and endogenous RB genes expressed their proteins at day 10.5, 12.5, and 17 of embryogenesis (Fig. 7B). These data strongly suggest that the $1.6-\mathrm{kb}$ human $\mathrm{RB}$ promoter, at least with regard to its tissue distribution
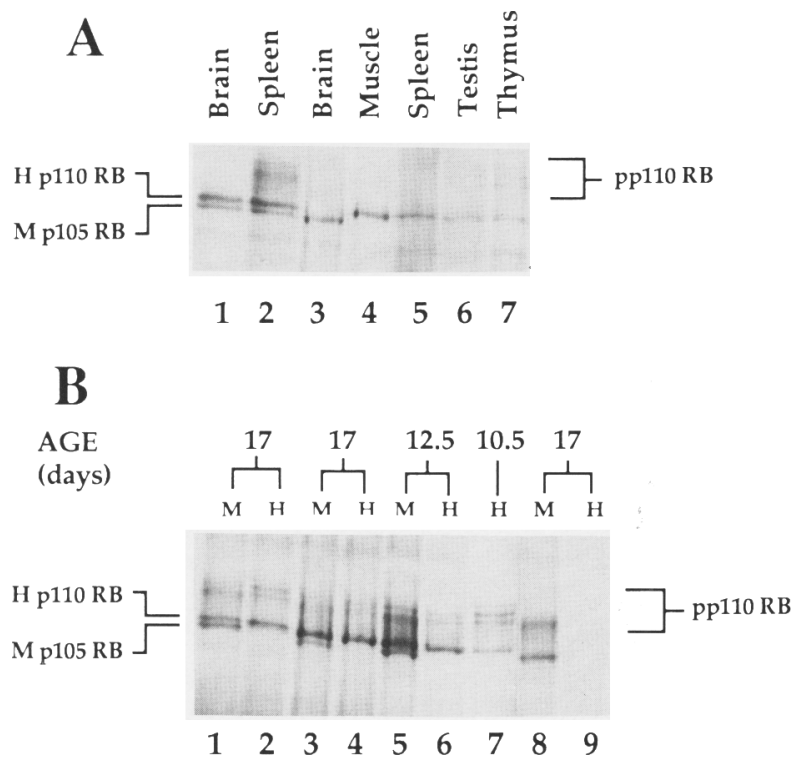

Figure 7. Expression of the transgenic RB protein in different tissues $(A)$ and different embryonic stages $(B)$ of RB.Rb-3 mice by Western blot analysis. $(A)$ Different tissues from an adult mouse were analyzed by immunoprecipitation as described in Figure $6 ; \mathrm{mAb} 245$ was used to immunoprecipitate the samples for lanes 1-3, and 0.495 was used for lanes 4-7. Brain tissue from a nontransgenic mouse was used as a control for mouse $R B$ protein (lane 3). All other lanes correspond to the tissues from one transgenic RB.Rb-3 mouse. $(B)$ Fetuses $(10.5,12.5$, and 17 days p.c.) were collected and analyzed as described above. Lanes 1 and 2 were from the 17-day-old fetuses of RB.Rb-1; and lanes 8 and 9 were from nontransgenic sibs. Lanes 3-7 were from RB.Rb-3 fetuses at different stages of development. and temporal pattern, is functionally similar to the endogenous RB promoter. The slow migrating forms of the transgenic and endogenous $\mathrm{RB}$ proteins, indicative of their greater phosphorylation state, were present in tissues derived from different stages of embryogenesis (Fig. 7B). These results suggest that both proteins may participate in cellular functions.

\section{Functional substitution of the transgene in "double-knockout" $R B$ mice}

To demonstrate definitively that the transgene is fully functional, it was necessary to create mice with a genetic background in which both alleles of the endogenous RB gene were inactivated. Transferring the transgene to such mice would enable us to test whether the transgene is functional. We have generated a strain of mice $\left(\mathrm{rb} / \mathrm{rb}^{\mathrm{m}}\right)$ with one allele of RB mutated at exon 20 through the embryonic stem cell technique (Lee et al. 1992). Mice with a homozygous mutation of RB are nonviable. Crossing RB.Rb3 mice with the $\left(\mathrm{rb} / \mathrm{rb}^{\mathrm{m}}\right)$ heterozygotes produced progeny with the genotype of $\left(\mathrm{rb} / \mathrm{rb}^{\mathrm{m}} ; \mathrm{hrb}=\right.$ the transgene). Intercrossing these progeny produced mice with the genotype of $\left(\mathrm{rb}^{\mathrm{m}} / \mathrm{rb}^{\mathrm{m}}\right.$, hrb $)$, as shown in Figure 8 , which are viable. The weights and genotypes shown in Figure 8 are representative examples of those obtained from several similar crossings. These results, as reported earlier (Lee et al. 1992), indicate that the transgene can functionally substitute for the endogenous mouse RB gene. When the body weights of three female mice from the same litter were measured, the heaviest one had the genotype $\left(\mathrm{rb}^{\mathrm{m}} / \mathrm{rb}^{\mathrm{m}}, \mathrm{hrb}\right)$ followed by $\left(\mathrm{rb} / \mathrm{rb}^{\mathrm{m}}\right.$, hrb $)$ and $(\mathrm{rb} / \mathrm{rb}, \mathrm{hrb})$, respectively. The difference in weight between mice of the $\left(\mathrm{rb}^{\mathrm{m}} / \mathrm{rb}^{\mathrm{m}}, \mathrm{hrb}\right)$ and $(\mathrm{rh} / \mathrm{rb}, \mathrm{hrb})$ genotypes is $\sim 25 \%$. These results suggested that copy number of endogenous wild-type mouse RB inversely correlates with body size.

\section{Discussion}

A relationship between the dosage of the RB protein and mammalian development can be established from these transgenic mice studies. As we have demonstrated here, mice that overexpress RB protein are smaller than nontransgenic littermates. The degree of dwarfism correlates inversely with the total amount of RB protein expressed in cells. If one assumes that the human RB protein is functionally equivalent to the mouse protein, as suggested by the rescue experiments, a $10-20 \%$ elevation of RB protein exerts an unusual effect on animal growth. The effect is maximal when exogenous $\mathrm{RB}$ protein is expressed at $\sim 100 \%$ of normal levels. In an attempt to measure the highest level of RB protein that a mouse could tolerate, several crosses between RB.Rb-1 and $\mathrm{RB} . \mathrm{Rb}-3$ individuals were made. One progeny with the genotype (Rb-1 + Rb-3), which carries a total of six to eight copies of the transgene, was produced; its body weight was $40 \%$ of that of nontransgenic sibs. This result suggests that a higher level of RB protein, slightly $>200 \%$ of endogenous RB levels, can be tolerated. How- 
123

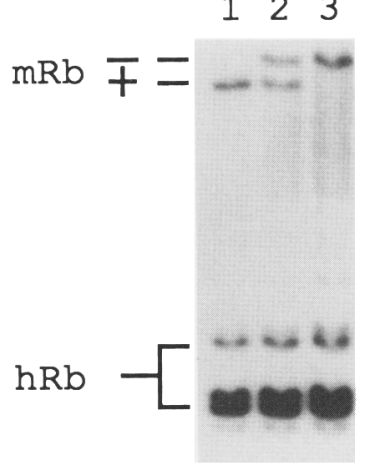

Genotype:

$$
\begin{aligned}
& \mathrm{mRb}+-- \\
& \mathrm{hRb}+++
\end{aligned}
$$

Body Weight $(g)$ :

$$
15.018 .1 \quad 19.4
$$

Figure 8. A correlation between the copy number of the wildtype RB gene and dwarf phenotype. The genotypes of three female offspring from a cross between heterozygotes with the genotype $\left(\mathrm{rb} / \mathrm{rb}^{\mathrm{m}}, \mathrm{hrb} 3\right)$ were determined by DNA blotting analysis. Ten micrograms of genomic DNA from these three mice was digested with EcoRI and probed with a mouse 5 '-junctional probe as described (Lee et al. 1992). (mRb) Mouse RB gene; (-) the mutated allele with slower migration band; $1+\mid$ the wildtype allele with a faster migration. The same blot was also hybridized with the human transgene probe as indicated by hRb. The summarized genotype of mouse 1 (lane 1 ) was $(\mathrm{rb} / \mathrm{rb}, \mathrm{hrb} 3$ ), mouse 2 (lane 2) was $\left(\mathrm{rb} / \mathrm{rb}^{\mathrm{m}}\right.$, hrb3) and mouse 3 (lane 3 ) was $\left(\mathrm{rb}^{\mathrm{m}} / \mathrm{rb}^{\mathrm{m}}\right.$, hrb3 $\mid$. Body weights of these 2 -month old mice were measured as shown in the bottom panel, indicating that when the copy number of $\mathrm{hRb}$ is the same, the body weights of mice correlate inversely with the copy number of endogenous, wildtype RB gene. Body weights of offspring from five similar crosses of mice with the genotype $\left(\mathrm{rb} / \mathrm{rb}^{\mathrm{m}}\right.$, hrb3) were measured, and the weights of mice with different genotypes were similarly inversely proportional to the mouse Rb gene copy number, as shown in the example here.

ever, very few progeny survived among the sibs, implying that this genotype may result in a high mortality rate. This observation is consistent with the finding that heterozygous offspring from the original RB.Rb-1 founder have four to five copies of the transgene deleted. In many cases, the copy number of the transgene can be $>50$ and remain stable (J. Windle, unpubl.). Our results suggest that there is a selection against higher copy numbers of the RB transgene. In the human, trisomy of chromosome 13 , on which the human RB gene is located, frequently results in spontaneous abortion. Although it is not certain which genes are involved in this process, overexpression of the RB gene may play an important role.

It is intriguing that overexpression of the $\mathrm{RB}$ protein in mice limits their growth. In cell culture, reintroduction of the wild-type RB gene into the osteosarcoma cells
(Saos-2) and the retinoblastoma cells (WERI-27), via retroviral-mediated gene transfer, retards the growth rates of the cells (Huang et al. 1988). Cytostatic effects were also observed if the exogenous RB gene was introduced by direct DNA transfection, which does not control for copy number (Qin et al. 1992). Similarly, microinjection of a 50-fold excess of RB protein into normal CV-1 cells also inhibits $G_{1}$ progression into $S$ phase (Goodrich et al. 1991). On the basis of all of these data, one can postulate that the effect of the RB protein on the growth of the cell is closely linked with and, perhaps, dependent on its dose, suggesting that the dosage problem of RB deserves serious consideration during the experimental process. The transgenic mouse study described here, consistent with the observations made in vitro, indicates that a systematic overexpression of RB generates an obvious effect on mouse growth.

It remains unclear why overexpression of $\mathrm{Rb}$ protein results in dwarf mice. Several mutant mice with a growth deficiency phenotype (dwarf) have been described. Among these are the Snell, Jackson, and Ames dwarf mutants, which contain no lactotrophs, somatotrophs, or thyrotrophs (Voss and Rosenfeld 1992). Interestingly, the Jackson and Snell dwarfs have been shown to result from the mutation of the Pit-1 gene, which regulates expression of the prolactin and growth hormone genes (Voss and Rosenfeld 1992). Recently, a growth-deficient mouse carrying an inactivated insulinlike growth factor II gene has been reported (DeChiara et al. 1990). The size of this new strain of mice is $\sim 60 \%$ that of normal littermates; the dwarfism is apparent at least as early as embryonic day 16 and persists after birth. Although the phenotypes of these dwarf mice are very similar to what we have described here for the RB transgenic mice, we have few clues to link the overexpression of RB to the deficiency of IGF-II or Pit-1 expression. Our preliminary results comparing the pituitary glands of dwarf RB-transgenic mice and wild-type mice, using standard histological stains and light microscopy, have revealed no differences between the glands in the two groups. These results suggest that the influence of $\mathrm{Rb}$ protein on pituitary gland development, if there is any, is subtle. Recent studies have provided evidence that RB may regulate several transcriptional factors either in a positive or negative manner (Chellappan et al. 1991; Kim et al. 1992). It is plausible to suggest that overexpression of the $\mathrm{RB}$ gene during embryogenesis may down-regulate the expression of certain key factors for controlling growth, such as growth hormone or IGFII.

Inactivation of the $\mathrm{RB}$ gene has been demonstrated in many different tumors, suggesting that $\mathrm{RB}$ is a common target of mutational events (Bookstein and Lee 1991). It would be of interest to determine whether extra copies of the RB gene could provide an additional protection from these genetic insults. To test this hypothesis, the transgenic mice described herein would be good models for experiments such as direct treatment of the amimals with carcinogens or crossing with cancer-prone mice (Sinn et al. 1987; Cory and Adams 1988; Windle et al. 
1990; C.-Y. Chang, D.J. Riley, E.Y.-H.P. Lee, and W.-H. Lee, in prep.).

\section{Materials and methods \\ Construction of the $R B$ transgene and production of transgenic mice}

Three DNA fragments, including the $1.6-\mathrm{kb} \mathrm{RB}$ promoter, which was defined in vitro and obtained from the plasmid of pRB-CAT (Hong et al. 1989), the 2.8-kb RB cDNA, which was derived from the plasmid of pRB44-2 (Wang et al. 1990b), and a $1.6-\mathrm{kb} \beta$-globin polyadenylation site, derived from pES4 (provided by $\mathrm{S}$. Hedrich), were used to construct the pBR-RB.Rb plasmid. The 6-kb SstI-HindIII DNA fragment containing the entire transgene was isolated from this plasmid and resuspended in $10 \mathrm{~mm}$ Tris $(\mathrm{pH} 7.5) / 0.25 \mathrm{~mm}$ EDTA at a concentration of $2 \mathrm{ng} / \mu \mathrm{l}$ for the injection into fertilized eggs of $F_{1}$ mice (C57BL/6 $\times \mathrm{BALB} / \mathrm{c})$, according to transgenic mouse construction procedures (Hogan et al. 1986).

\section{Statistical analysis of differences in body mass between transgenic and wild-type mice}

The mean masses of mouse littermates, controlled for sex, were calculated after recording all mouse masses in grams every other day between 20 and 70 days after birth. To determine the statistical significance of the differences between the masses of wild-type and transgenic mice within each line, Student's $t$-test was performed comparing the means of transgenic and wildtype mice from at least 14 individuals born consecutively in each line. The calculated $t$-distribution values for rejecting the null hypothesis (i.e., that the differences in mass could be attributed merely to chance) were greater in all lines than the one-tailed $t$-distribution values required to achieve significance to a level of $<3 \%$.

\section{Identification of transgenic mice by Southern blot analysis}

Tail DNA from 3-week-old mice was extracted by the proteinase K-SDS method (Hogan et al. 1986) and digested with the restriction enzyme BamHI. The blot was hybridized with probes of either DNA fragments containing the entire transgene or portions of it or with a 600 -bp NcoI fragment of p53 genomic DNA (including exons 2,3 , and 4), which served as a standard to calibrate the total loaded DNA. The blot was hybridized in $50 \%$ formamide and washed using stringent conditions to avoid cross hybridization with the endogenous RB gene (Sambrook et al. 1989). Quantitation of the copy number was performed either by densitometry of the autoradiograms with a LKB Ultroscan XL densitometer or directly measured by Betascope 603 (Betagene).

\section{Immunoprecipitation and Western blot analysis}

The antibodies used, mAb 245 (labeled M for mouse) and 0.495 (labeled $\mathrm{H}$ for human), have been described previously (Wang et al. 1990a). Molt-4 cells, a human T-cell leukemia line (Drexler et al. 1987), and NIH-3T3 cells were used as positive controls for human RB and mouse RB protein, respectively. Dissected lung tissues were frozen immediately on dry ice or in liquid nitrogen and then stored at $-80^{\circ} \mathrm{C}$. The tissues were powdered and dissolved in $1 \mathrm{ml}$ of lysis buffer $(50 \mathrm{mM}$ Tris/ $\mathrm{HCl}$ at $\mathrm{pH} 7.4 ; 0.25 \mathrm{M}$ $\mathrm{NaCl} ; 0.1 \%$ NP-40; 5 mM EDTA; $50 \mathrm{~mm} \mathrm{NaF} ; 1 \mathrm{~mm}$ PMSF; 50 $\mu \mathrm{g} / \mathrm{ml}$ of aprotinin; $50 \mathrm{~mm}$ leupeptin), and then clarified by centrifugation for $10 \mathrm{~min}$ at $4^{\circ} \mathrm{C}$. The supernatant proteins were quantitated using the Bio-Rad protein assay, following the recommendations of the manufacturer (Bio-Rad Laboratories, Richmond, CA). The same amount of protein from each tissue was immunoprecipitated by either mAb 245 or the polyclonal antibody 0.495 . The resulting immune complexes were absorbed by protein A-Sepharose beads and washed twice on ice with $1 \mathrm{ml}$ of NET-N solution $(20 \mathrm{mM}$ Tris at $\mathrm{pH} 8.0 ; 100 \mathrm{~mm}$ $\mathrm{NaCl} ; 1$ mm EDTA; $0.5 \%$ NP-40). The immune complexes were electrophoresed through a $7.5 \%$ SDS-polyacrylamide gel and transferred to an Immobilon membrane (Millipore), as described previously (Chen et al. 1989). RB proteins were identified by $\mathrm{mAb} 245$ and detected by an alkaline phosphatase-labeled antimouse immunoglobulin secondary antibody (Promega) as described by the manufacturer.

\section{Acknowledgments}

We thank C. Landel for his technical assistance, Z.D. Sharp for critical comments, and $\mathrm{K}$. Benirschke for providing references of trisomy 13. Y.-J.B. was a visiting fellow supported by the Ligue Nationale contre le Cancer (comité du Puy De Dôme) and the Centre Jean Perrin (Clermont-Ferrand, France). This work was initiated at University of California, San Diego, and supported by grants to W.-H.L. from the National Institutes of Health (CA 58318) and the Council for Tobacco Research-USA.

The publication costs of this article were defrayed in part by payment of page charges. This article must therefore be hereby marked "advertisement" in accordance with 18 USC section 1734 solely to indicate this fact.

\section{References}

Bernards, R., G.M. Schackleford, M.R. Gerber, J.M. Horowitz, S.H. Friend, M. Schartl, E. Bogenmann, J.M. Rapaport, T. McGee, T.P. Dryja, and R.A. Weinberg. 1989. Structure and expression of the murine retinoblastoma gene and characterization of its encoded protein. Proc. Natl. Acad. Sci. 86: 6474-6478.

Bienz, B., R. Zakut-Houri, D. Givol, and M. Oren. 1984. Analysis of the gene coding for the murine cellular tumor antigen p53. EMBO I. 3: 2179-2183.

Bignon, Y.-J., J.-Y. Shew, D. Rappolee, S.L. Naylor, E.Y.-H.P. Lee, J. Schnier, and W.-H. Lee. 1990. A single Cys706 to Phe substitution in the retinoblastoma protein causes the loss of binding to SV40 T antigen. Cell Growth Differ. 1: 647-653.

Bookstein, R. and W.-H. Lee. 1991. Molecular genetics of the retinoblastoma suppressor gene. CRC Crit. Rev. Oncogen. 2: 211-227.

Bookstein, R., J.-Y. Shew, P.-L. Chen, P. Scully, and W.-H. Lee. 1990. Suppression of tumorigenicity of human prostate carcinoma cells by replacing a mutated $R B$ gene. Science 247: 712-715.

Buchkovich, K., L.A. Duffy, and E. Harlow. 1989. The retinoblastoma protein is phosphorylated during specific phases of the cell cycle. Cell 58: 1097-1105.

Chellappan, S., S. Hiebert, M. Mudryi, J.M. Horowitz, and J.R. Nevins. 1991. The E2F transcription factor is a cellular target for the RB protein. Cell 65: 1053-1061.

Chen, P.-L., P. Scully, J.-Y. Shew, J.Y.-J. Wang, and W.-H. Lee. 1989. Phosphorylation of the retinoblastoma gene product is modulated during the cell cycle and cellular differentiation. Cell 58: 1193-1198.

Cory, S. and J.A. Adams. 1988. Transgenic mice and oncogenesis. Annu. Rev. Immunol. 6: 25-48.

DeCaprio, J.A., J.W. Ludlow, J. Figge, J.-Y. Shew, C.-M. Huang, 
W.-H. Lee, E. Marsillo, E. Paucha, and D.M. Livingston. 1988. SV40 large tumor antigen forms a specific complex with the product of the retinoblastoma susceptibility gene. Cell 54: 275-283.

DeCaprio, J.A., J.W. Ludlow, D. Lynch, Y. Furukawa, J. Griffin, H. Pawnica-Worms, C.-M. Huang, and D.M. Livingston. 1989. The product of the retinoblastoma susceptibility gene has properties of a cell cycle regulatory element. Cell 58: 1085-1095.

DeChiara, T.M., A. Efstratiadis, and E.J. Robertson. 1990. A growth-deficiency phenotype in heterozygous mice carrying an insulin-like growth factor II gene disrupted by targeting. Nature 345: 78-80.

Drexler, H.G., G. Galdicke, and J. Minowada. 1987. T-leukemia cell lines CCRF-CEM, HPB-ALL, IM and MOLT-4: Changes in isoenzyme profiles during induction of differentiation. Blut 54: 79-87.

Friend, S.H., R. Bernards, S. Rogelj, R.A. Weinberg, J.M. Rapaport, D.M. Albert, and T.P. Dryia. 1986. A human DNA segment with properties of the gene that predisposes to retinoblastoma and osteosarcoma. Nature 323: 643-646.

Friend, S.H., J.M. Horowitz, M.R. Gerber, X.-F. Wang, E. Bogenman, F.P. Li, and R.A. Weinberg. 1987. Deletions of a DNA sequence in retinoblastomas and mesenchymal tumors: Organization of the sequence and its encoded protein. Proc. Natl. Acad. Sci. 84: 9059-9063.

Fung, Y.K.T., A.L. Murphree, A. T'Ang, J. Qian, S.H. Hinrichs, and W.F. Benedict. 1987. Structural evidence for the authenticity of the human retinoblastoma gene. Science 236: 16571661 .

Goodrich, D.W., Y. Chen, P. Scully, and W.-H. Lee. 1992. Expression of the retinoblastoma gene product in bladder carcinoma cells associates with a low frequency of tumor formation. Cancer Res. 52: 1968-1973.

Goodrich, D.W., N.P. Wang, Y.-W. Qian, E.Y.-H.P. Lee, and W.H. Lee. 1991. The retinoblastoma gene product regulates progression through the Gl phase of the cell cycle. Cell 67: 293-302.

Hogan, B., F. Constantini, and E. Lacy. 1986. Manipulating the mouse embryo: A laboratory manual. Cold Spring Harbor Laboratory, Cold Spring Harbor, New York.

Hong, F.D., H.-J.S. Huang, H. To, L.-J.S. Young, A. Oro, R. Bookstein, E.Y.-H.P. Lee, and W.-H. Lee. 1989. Structure of the human retinoblastoma gene. Proc. Natl. Acad. Sci. 86: 5502-5506.

Horowitz, J.M., D.W. Yandell, S.H. Park, S. Canning, P. Whyte, K. Buchkovich, E. Harlow, R. Weinberg, and T. Dryja. 1989. Point mutational inactivation of the retinoblastoma antioncogene. Science 243: 937-940.

Huang, H.-J.S., J.-K. Yee, J.-Y. Shew, P.-L. Chen, R. Bookstein, T. Friedmann, E.Y.-H.P. Lee, and W.-H. Lee. 1988. Suppression of the neoplastic phenotype by replacement of the retinoblastoma gene product in human cancer cells. Science 242: $1563-1566$

Kim, S.-J., S. Wagner, F. Liu, M.A. O'Reilly, P.D. Robbins, and M.R. Green. 1992. Retinoblastoma gene product activates expression of the human TGF-b2 gene through transcription factor ATF-2. Nature 358: 331-334.

Lee, E.Y.-H.P., C.-Y. Chang, N. Hu, Y.-C.J. Wang, K. Herrup, W.-H. Lee, and A. Bradley. 1992. Mice deficient for RB are nonviable and show defects in neurogenesis and hematopoiesis. Nature 359: 288-294.

Lee, W.-H., R. Bookstein, and E.Y.-H.P. Lee. 1988. Studies on the human retinoblastoma susceptibility gene. J. Cell. Biochem. 38: 213-227.

Lee, W.-H., R. Bookstein, F. Hong, L.-J. Young, J.-Y. Shew, and
E.Y.-H.P. Lee. 1987a. Human retinoblastoma susceptibility gene: Cloning, identification, and sequence. Science 235: 1394-1399.

Lee, W.-H., J.-Y. Shew, F. Hong, T. Sery, L.A. Donoso, L.J. Young, R. Bookstein, and E.Y.-H.P. Lee. 1987b. The retinoblastoma susceptibility gene product is a nuclear phosphoprotein associated with DNA binding activity. Nature 329: 642-645.

Lees, J.A., K.J. Buchkovich, D.R. Marshak, C.W. Anderson, and E. Harlow. 1991. The retinoblastoma protein is phosphorylated on multiple sites by human cdc2. EMBO /. 10: 42794290.

Lin, B.T., S. Gruenwald, A.O. Morla, W.-H. Lee, and J.Y. Wang. 1991. Retinoblastoma cancer suppressor gene product is a substrate of the cell cycle regulator cdc2 kinase. EMBO $I$. 10: $857-864$.

Qin, X.-Q., T. Chittenden, D.M. Livingston, and W.G. Kaelin. 1992. Identification of a growth suppression domain within the retinoblastoma gene product. Genes \& Dev. 6: 953-964.

Sambrook, J., E. F. Fritsch, and T. Maniatis. 1989. Molecular cloning: A laboratory manual, 2nd ed. Cold Spring Harbor Laboratory Press, Cold Spring Harbor, New York.

Shew, J.-Y., B. Lin, P.-L. Chen, B.Y. Tseng, T.L. Yang-Feng, and W.-H. Lee. 1990. C-terminal truncation of the RB protein leads to functional inactivation. Proc. Natl. Acad. Sci. 87: 610.

Shew, J.-Y., N. Ling, X. Yang, O. Fodstad, and W.-H. Lee. 1989. Antibodies detecting abnormalities of the retinoblastoma susceptibility gene product (ppl10RB) in osteosarcomas and synovial sarcomas. Oncogene Res. 1: 205-214.

Sinn, E., W.J. Muller, P.K. Pattengale, I. Tepler, R. Wallace, and P. Leder. 1987. Coexpression of MMTV/v-Ha-ras and MMTV/c-myc genes in transgenic mice: Synergistic action of oncogene in vivo. Cell 49: 465-475.

Sumegi, J., E. Uzvolgyi, and G. Klein. 1990. Expression of the RB gene under the control of MuLV-LTR suppresses tumorigenicity of WERI-Rb-27 retinoblastoma cells in immunodefective mice. Cell Growth Differ. 1: 247-250.

Takahashi, R., T. Hashimoto, X. Hong-Ji, S.-X. Hu, T. Matsui, T. Miki, H. Bigo-Marshall, S.A. Aaronson, and W.F. Benedict. 1991. The retinoblastoma gene functions as a growth and tumor suppressor in human bladder carcinoma cells. Proc. Nat1. Acad. Sci. 88: 5257-5261.

Templeton, D.J., S.H. Park, L. Lanier, and R.A. Weinberg. 1991. Nonfunctional mutants of the retinoblastoma protein are characterized by defects in phosphorylation, viral oncoprotein association, and nuclear tethering. Proc. Natl. Acad. Sci. 88: 3033-3037.

Voss, J.W. and M.G. Rosenfeld. 1992. Anterior pituitary development: Short tales from dwarf mice. Cell 70: 527-530.

Wang, N.P., P.-L. Chen, S. Huang, L.A. Donoso, W.-H. Lee, and E.Y.-H.P. Lee. 1990a. DNA-binding activity of retinoblastoma protein is intrinsic to its carboxyl-terminal region. Cell Growth Differ. 1: 233-239.

Wang, N.P., Y. Qian, A.E. Chung, W.-H. Lee, and E.Y.-H.P. Lee. 1990b. Expression of the human retinoblastoma gene product ppll0RB in insect cells using the baculovirus system. Cell Growth Differ. 1: 429-437.

Whyte, P., K.J. Buchkovich, J.M. Horowitz, S.H. Friend, M. Raybuck, R.A. Weinberg, and E. Harlow. 1988. Association between an oncogene and an anti-oncogene: The adenovirus ElA proteins bind to the retinoblastoma gene product. $\mathrm{Na}$ ture 334: 124-129.

Windle, J.J., D.M. Albert, J.M. O'Brien, D.M. Marcus, C.M. Disteche, R. Bernards, and P.L. Mellon. 1990. Retinoblastoma in transgenic mice. Nature 343: 665-669. 


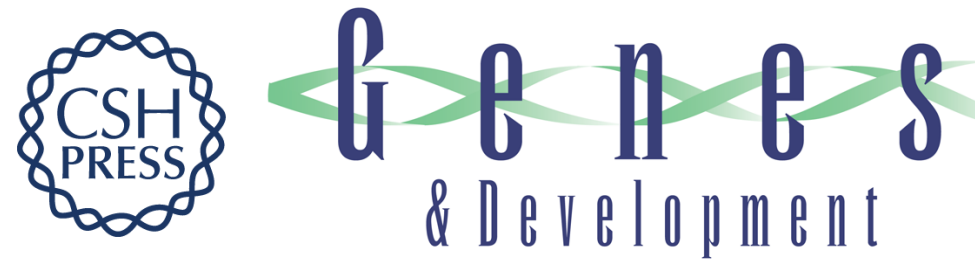

\title{
Expression of a retinoblastoma transgene results in dwarf mice.
}

\author{
Y J Bignon, Y Chen, C Y Chang, et al.
}

Genes Dev. 1993, 7:

Access the most recent version at doi:10.1101/gad.7.9.1654

\section{References This article cites 40 articles, 17 of which can be accessed free at: http://genesdev.cshlp.org/content/7/9/1654.full.html\#ref-list-1}

\section{License}

Email Alerting

Receive free email alerts when new articles cite this article - sign up in the box at the top Service right corner of the article or click here.

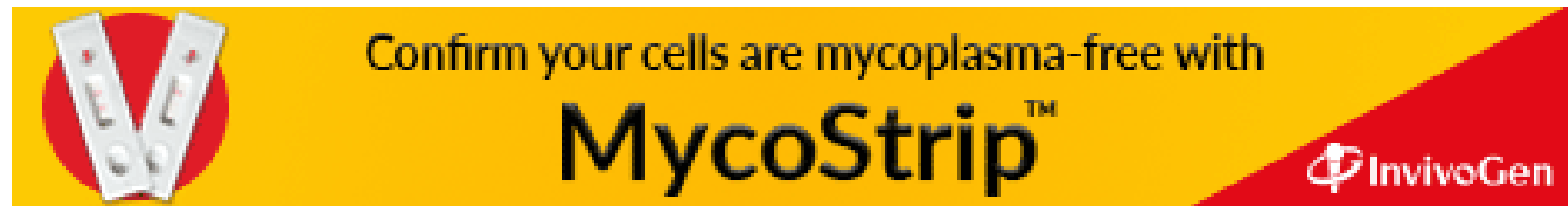

